\section{Marble provenance investigation of the Roman Sabine sarcophagus}

\section{Fred White}

Florida Archaeological Survey, Gainesville, FL, USA

\section{Abstract}

The provenance of marbles used for making sarcophagi during the Roman period is an important question and scientific analysis can provide a strong confirmation and basis for future studies determining when and where the materials were obtained for manufacture. By using three different techniques (i.e., electron paramagnetic resonance spectroscopy, stable isotope analysis and maximum grain size measurements) plus in situ examination, it is possible to resolve fully the provenance and date range of the ancient marble.

\section{Introduction}

In early Roman times, the bodies of the dead were traditionally cremated, but in the first and second centuries of the Common Era, Romans began to preserve dead bodies intact in full-size sarcophagi (from the Greek sarkophágos, meaning flesh eating, as the lime content in marble would quickly dissolve flesh). It was not until after the days of Trajan (Roman Emperor from 98 to 117 A.D.) that the Romans produced the monumental and richly sculptured examples which are found in the museums of Europe today. Sarcophagi were designed to remain above ground, hence were often ornately carved, decorated or elaborately constructed. Christian burial practice and preference for interment underground sharply ended the use of the Roman burial rites and the use of sarcophagi just after the year 300 A.D.

Ancient Carrara marble sarcophagi were in use during such a narrow date range centred in the $2^{\text {nd }}$ century A.D. during the Imperial Period they are considered rare. It is important that the marbles from which Roman funerary monuments were constructed are scientifically studied and catalogued. The provenance defines which ancient quarry the material came from and the historical period the quarry was in use. That data can often answer questions about local use, trade and the quality of workmanship.

The sarcophagus illustrating the Rape of the Sabine Women is believed to have been obtained in Rome between 1900 and 1904 by Alfred Emerson, Professor and Chair of Classical Archaeology at Cornell University and the Curator of Antiquities at the Art Institute of Chicago for Phoebe A. Hearst. Professor Emerson was an experienced field archaeologist having excavated sites in Greece and North Africa. He was educated at the University of Munich and Princeton University, and was a Fellow at Johns Hopkins University.

In 1919 thence by descent the Sabine sarcophagus was transferred from the collection of Phoebe A. Hearst to her son William Randolph Hearst. In 1928 financial pressures from the Great Depression mounted and Hearst was no longer in control of his holdings and in 1937 a court mandated reorganisation of the Hearst Corporation forced the beginning of years of art and antiquities liquidation for Hearst. More than 20,000 treasured items including George Washington's waistcoat, Charles Dickens's sideboard, van Dyke paintings, and even Thomas Jefferson's Bible were put on sale through many private dealers; even today the extent of the collection items sold is unknown. In 1957 the Hearst Corporation transferred ownership of the Hearst Castle and its remaining contents including one Roman marble sarcophagus $c a .230$ A.D. with the iconography of the Nine Muses to the State of California. Many other antiquities were held in trusts. Documentary evidence, including bills of sale, affidavits and photography confirm the Sabine circa $2^{\text {nd }}$ century A.D. Roman sarcophagus was purchased in 1962 from an antique auction of items from the collection of William Randolph Hearst which had been held in trust. There is complete pre-1970 [United Nations Educational, Scientific and Cultural Organization (UNESCO)] provenance.

The Sabine sarcophagus is of ancient Roman date and you can still see the cuttings for and traces of the Roman iron clamps that once held the lid in place. From the blocked drain holes in one end we know the sarcophagus was reused at some stage of its history as a water basin, a common fate of Roman sarcophagi. The carved ends and back demonstrate cracks which must post-date not only the decoration, but also the use of the sarcophagus as a water basin. The cracks were mended using an iron bar across the top in the $19^{\text {th }}$ century, when it entered a private collection.

Sarcophagi were often reused for interment of other individuals and nearly all extant examples including the ones at the Vatican demonstrate some slight re-styling to update the relief to include family elements of the newly interred. The two greatest sarcophagi of the Roman Empire both in point of artistic merit and size were pilfered from their original tombs and put to use for a second occupant. The Sarcophagus of Porphyry in the Vatican
Correspondence: Fred A. White, Florida Archaeological Survey, East Hwy 316, 32113-7408 Gainesville, FL, USA. Tel/Fax: +1.352.817.2651.

E-mail: nationalarchaeology@mail.com

Key words: sarcophagus, marble, provenance, quarry, Roman.

Acknowledgments: the author expresses gratitude to Donato Attanasio [The Institute of the Structure of Matter of the Italian National Research Council (Consiglio Nazionale delle Ricerche - Istituto di Struttura della Materia), Rome, Italy] and Julia Cox (Department of Geology, University of Georgia, Athens, GA, USA) for laboratory testing. Sincere thanks to Dr. Michele White, for logistical and historical research and Ethan White, of Trinity History Honors, for archival repair work to conserve the Sabine sarcophagus. The faculty and staff at Rollins College are also thanked for allowing the rare Sabine sarcophagus to be used in academic research and incorporating the sepulchral relief in curricula for the enriched study of the humanities. Special thanks to: Dr. Ena Heller, Director of the Cornell Fine Arts Museum at Rollins College; Dr. Robert Vander Poppen, Assistant Professor of Classical Art and Archaeology and the Archaeology Program Coordinator at Rollins College; Dr. Amy Galpin, Curator of the Cornell Fine Arts Museum.

Conflict of interests: the author declares no potential conflict of interests.

Funding: this paper was funded by the Florida Archaeological Survey Archaeometry Project.

Presented at the $38^{\text {th }}$ International Symposium on Archaeometry - May $10^{\text {th }}-14^{\text {th }} 2010$, Tampa, Florida.

This work is licensed under a Creative Commons Attribution 3.0 License (by-nc 3.0).

(C) Copyright F. White, 2014

Licensee PAGEPress, Italy

Open Journal of Archaeometry 2014; 2:5232

doi:10.4081/arc.2014.5232

was proven to be the original sarcophagus of Emperor Marcus Aurelius in 1922. It had been stolen from the mausoleum of Hadrian by Emperor Constantine in order to place in it the body of his mother Helena with restyling. The Ludovisi sarcophagus is believed to originally contain the body of one of the leading generals of Marcus Aurelius, killed in one of the northern wars. A century after his death, his tomb was desecrated; his body thrown out of the sarcophagus and re-cut to represent the new occupant. Thus, the Ludovisi is a work from near 170 A.D. instead of about 270 A.D. (Frothingham, 1922). During the eleventh century re-use of sarcophagi became the vogue of the powerful and by the thirteenth century these type vessels became extremely scarce 
and not long after that became valuable collector pieces.

The quality of relief carving on the Sabine sarcophagus is very telling to all Roman art history scholars as it is not considered high polished bas-relief. This confirms the date range as most surviving personal reliefs contained similar elements as state imperial reliefs, however they were not as highly refined as state examples. Art historians correlate this with the Antonine Plague falling within the same period as this sarcophagus. Personal sculpture quality suffered during this time as the quality of state work was consistent. These are all important classic details in the carving of Roman sarcophagi.

The floor of the Sabine sarcophagus slopes properly upward toward the head end and internally is rounded, where the internal of the foot area is squared. All of marble sides demonstrate a very consistent width of $7 \mathrm{~cm}$.

In contrast to the rough and partially patterned back corners, the front of the Sabine sarcophagus is decorated with sixteen human figures carved in high relief. In the background there is an Ionic order temple, historically the one dedicated to Quirinus, a Sabine cult god of war, located on the Collis Quirinalis. The central theme is the Raptus of the Sabine Women. This imagery evolved from the legendary history of Rome, in which the men of the area acquired wives from the neighbouring Sabine families. This iconography is one of the traditional heroic themes found in relief carvings, as the Sabine women are revered as the mothers of the first Romans. Roman culture had a long history of decorating reliefs with what are categorised as heroic rape scenes. The subjects from early history in these myths included the Sabines, Daphne, Io, Europa, Proserpina, Leucippus and Leda. The stories portraying the heroic rape iconography are extremely complex and represent a violence that begins with the abduction of the women. In ancient Rome the term raptus (rape) was defined as a crime of theft, essentially to carry away by force.

On the Sabine sarcophagus the women are wearing chiton and himation drapes common in $c a .1^{\text {st }-2^{\text {nd }}}$ century A.D. period sculpture. The particular hairstyles of the women and men were popularised during the Julio-Claudian Period, $c a .1^{\text {st }}$ century A.D. and continued throughout the Antonine Period. The iconography also displays Roman legionary uniforms which demonstrate accurately the period skirt with leather tassets, tunic, sagum drape and the one shoulder baldric belts. Imperial helmets of the $1^{\text {st }} 2^{\text {nd }}$ century were designed to attach crests, but the crests were seldom used in battle, thus the portrayal here of helmets with horsehair crests fits within the context of the narrative in which the Sabine women were abducted during the Festival of Neptunus

\section{Equester.}

The right end of the sarcophagus is decorated with the curved oval scutum shield of the Praetorium Guardsmen, with a quiver and plumbata dart spear carved in relief. The reliefs on Trajan's Column in Rome depict the oval scutum used by the Praetorium and auxiliaries during a military operation against the Dacians of southeastern Europe. The left end is decorated with a six sided shield and Roman legionary gladius sword with belt and scabbard carved in relief. Similar six sided shields are found in iconography among a Roman marble sarcophagus relief fragment from the Antonine Period, $c a$. A.D. 161-192 and seen in the Column of Marcus Aurelius in Rome, demonstrating the close link between personal sarcophagi and state imperial relief sculpture of the time. The carving appears to be from the same workshop as that of the Alcestis, The Metilia Acte sarcophagus, in the Vatican Museo Chiaromonti (Figure 1). The date of

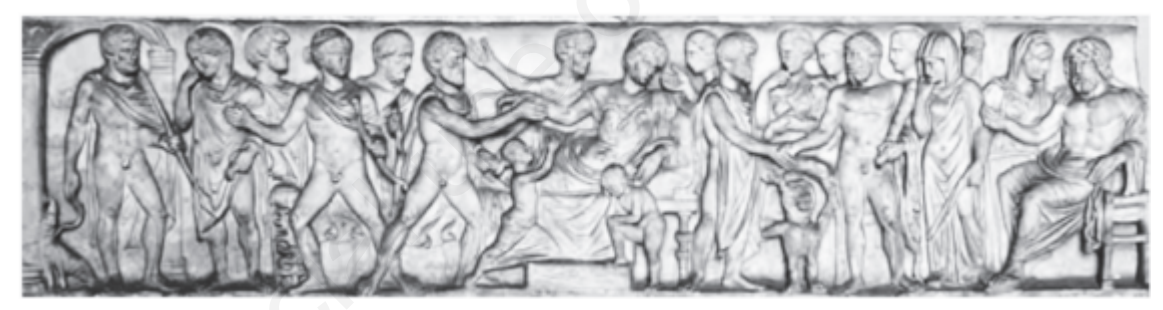

Figure 1. Alcestis, The Metilia Acte sarcophagus, Vatican Museo Chiaromonti (160-170 A.D.).

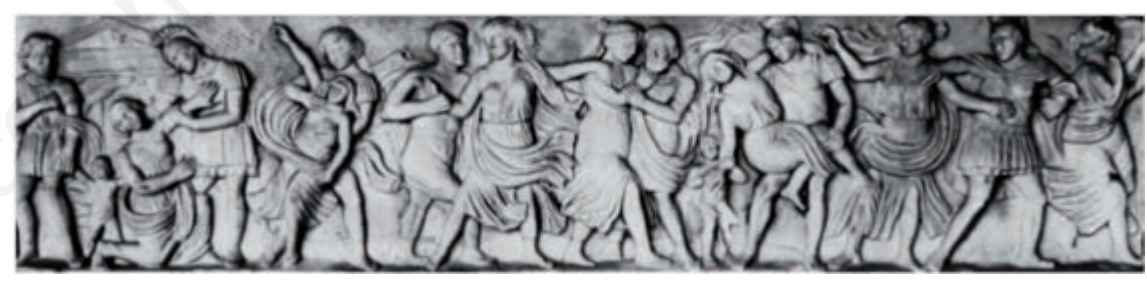

Figure 2. The Raptus of the Sabines sarcophagus (ca. $2^{\text {nd }}$ century A.D.).

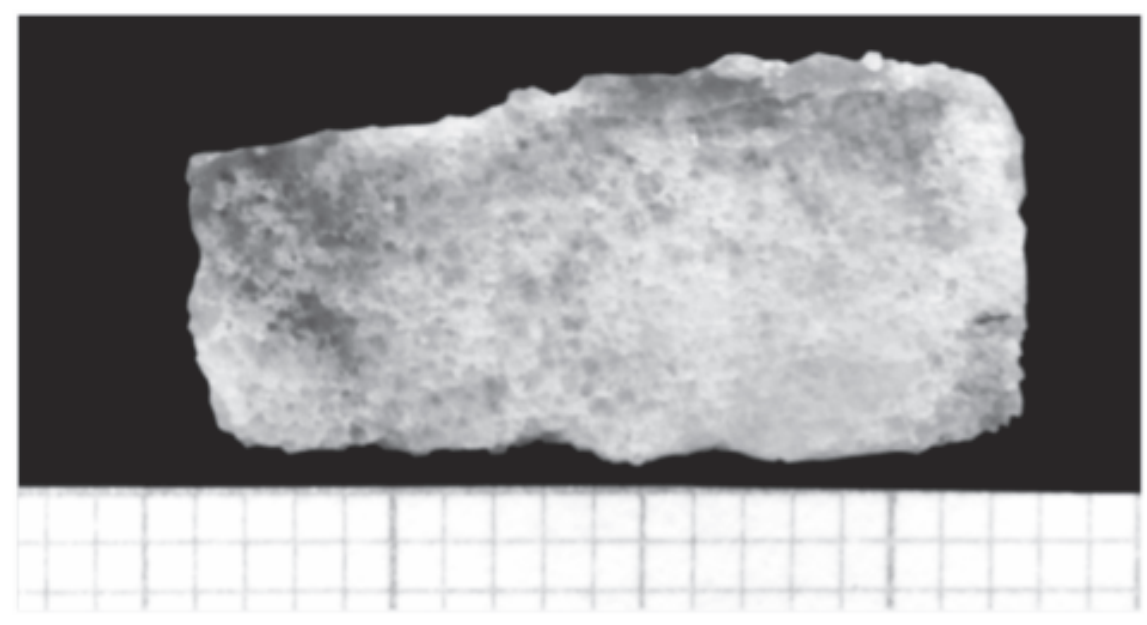

Figure 3. Marble sample (10 g) from Sabine sarcophagus. that piece is indisputable for the inscription places it between 160-170 A.D.

The Sabine bas-relief sarcophagus (Figure 2) is an exquisite example of Roman funerary art, which is both ornate and well preserved. a well to do individual would have been member of one of the older aristocratic families in Rome.

\section{Materials and Methods}

A 2.0 gram marble sample to be powdered for isotopic analysis along with a 10.0 gram marble sample in solid block form (Figure 3) Sabine sarcophagus.

The provenance of the Sabine marble sarcophagus has been obtained using a combinacommission and purchase such a sar- 
tion of different analytical properties which include the oxygen and carbon stable isotopes ratios, the petrographic and morphological variables [maximum grain size (MGS)] and colour, and the electron paramagnetic resonance (EPR) spectroscopy properties of the sample (spectroscopic intensity and spectroscopic linewidth) (Moens et al., 1992).

The MGS was determined by examining a block sample (Figure 3) obtained from the rim of the Sabine sarcophagus with an optical microscope, millimeter scale and comparison samples. Additional cleaned and ground samples were prepared from the 10 gram block for EPR spectroscopy. Samples between the fractions of 60 and $180 \mathrm{~mm}$ were selected and the analysis was carried on the Bruker ER-200SRC spectrometer (Bruker, Billerica, MA, USA). Samples retrieved from the same location on the Sabine sarcophagus were powdered into very fine grain fractions of less than $60 \mathrm{~mm}$ in size for aliquots. These samples submitted for isotope ratio mass spectrometry were measured relative to the Vienna PeeDee Belemnite (VPDB) standard and are expressed in delta values with the standard error value of $10.1 \%$ that determine the oxygen and carbon stable isotope ratios.

Electron paramagnetic resonance spectroscopy detects and measures the manganese impurity always present in marbles and therefore can be considered as a special case of trace analysis. Only the manganese that substitutes calcium into the crystal lattice of calcite is detected and this explains the high discriminant power of the technique. Conventional techniques, in fact, detect also interstitial impurities which are due to the presence of trace minerals. Large variabilities are usually measured and this greatly decreases the discriminant power of the analyses (Polikreti and Maniatis, 2002).

The carbon and oxygen stable isotopic measurement were determined and the results below are reported in per mil relative to VPDB:

$$
\delta^{13} \mathrm{C}=+2.06 \text { and } \delta^{18} 0=-1.80
$$

PeeDee Belemnite is the traditional reference for carbon and oxygen stable isotopic measurements. PeeDee Belemnite is a fossil composed of the mineral calcite. When the original reference material ran out, it was decided by consensus to replace it with anoth- er calcite standard known as [National Bureau of Standards (NBS)-19] that has an isotopic composition defined relative to PDB. Thus, a lab that calibrates using NBS-19 should report results relative to VPDB. In practice, there should be no difference between results reported relative to PDB or VPDB (Herz, 1985, 1987, 1988; Attanasio et al., 2006).

The rate of success of the combined methods is $82 \%$. This means that $82 \%$ of the database samples are correctly re-assigned to their true quarries of provenance using the statistical classification rule. The Sabine sample is assigned to the ancient quarry of provenance and the results are deemed to be statistically reliable if the probability values are above their thresholds.

\section{Results}

The analytical results listed in Table 1 indicate that the Sabine sample is a fine grained marble (MGS $=0.7 \mathrm{~mm}$ ). Therefore, its provenance can be established within a subset of the general marble database including only the

Table 1. Analytical data for the Sabine sample compared with a selection of ancient marble sites considered as possible provenances. The site analytical properties are summarised by the means and the total variability range of the analytical variables.

\begin{tabular}{|c|c|c|c|c|c|c|c|}
\hline No. & $\begin{array}{c}\text { Description } \\
\text { (no. of samples) }\end{array}$ & $\begin{array}{l}\text { MGS } \\
(\mathrm{mm})\end{array}$ & $\begin{array}{l}\delta 180 \\
(\% 0)\end{array}$ & $\begin{array}{l}\delta 13 \mathrm{C} \\
(\%)\end{array}$ & $\begin{array}{l}\text { EPR intensity } \\
\qquad \%)\end{array}$ & $\begin{array}{l}\text { EPR line width } \\
(\%)\end{array}$ & $\begin{array}{l}\text { Colour } \\
(\%)\end{array}$ \\
\hline 1 & $\begin{array}{l}\text { Sabine } \\
\text { (1) }\end{array}$ & 0.7 & -1.80 & 2.06 & 76.8 & 56.3 & 75 \\
\hline 2 & $\begin{array}{c}\text { Carrara } \\
(112)\end{array}$ & $\begin{array}{c}0.80 \\
(0.4 / 1.4)\end{array}$ & $\begin{array}{c}-1.89 \\
(-3.0 /-0.5)\end{array}$ & $\begin{array}{c}2.11 \\
(1.1 / 2.6)\end{array}$ & $\begin{array}{c}68.5 \\
(10 / 237)\end{array}$ & $\begin{array}{c}63.4 \\
(55 / 80)\end{array}$ & $\begin{array}{c}83 \\
(57 / 99)\end{array}$ \\
\hline 3 & $\begin{array}{l}\text { Pentelicon } \\
\text { (154) }\end{array}$ & $\begin{array}{c}0.96 \\
(0.6 / 1.8)\end{array}$ & $\begin{array}{c}-7.00 \\
(-9.0 /-3.8)\end{array}$ & $\begin{array}{c}2.63 \\
(1.9 / 4.1)\end{array}$ & $\begin{array}{c}226.3 \\
(13 / 1009)\end{array}$ & $\begin{array}{c}58.2 \\
(38 / 100)\end{array}$ & $\begin{array}{c}90 \\
(68 / 97)\end{array}$ \\
\hline 4 & $\begin{array}{l}\text { Hymettos } \\
\text { (41) }\end{array}$ & $\begin{array}{c}0.69 \\
(0.4 / 1.2)\end{array}$ & $\begin{array}{c}-2.17 \\
(-4.3 /-1.2)\end{array}$ & $\begin{array}{c}2.20 \\
(0.9 / 3.2)\end{array}$ & $\begin{array}{c}14.2 \\
(1 / 75)\end{array}$ & $\begin{array}{c}46.0 \\
(36 / 54)\end{array}$ & $\begin{array}{c}71 \\
(53 / 90)\end{array}$ \\
\hline 5 & $\begin{array}{c}\text { Docimium (Ischehisar) } \\
(65)\end{array}$ & $\begin{array}{c}0.86 \\
(0.5 / 1.5)\end{array}$ & $\begin{array}{c}-4.32 \\
(-7.7 /-2.3)\end{array}$ & $\begin{array}{c}1.80 \\
(-1.4 / 3.1)\end{array}$ & $\begin{array}{c}242.5 \\
(6 / 627)\end{array}$ & $\begin{array}{c}53.9 \\
(40 / 68)\end{array}$ & $\begin{array}{c}76 \\
(56 / 98)\end{array}$ \\
\hline 6 & $\begin{array}{l}\text { Docimium (Altintaş) } \\
(48)\end{array}$ & $\begin{array}{c}0.67 \\
(0.4 / 1.2)\end{array}$ & $\begin{array}{c}-5.38 \\
(-9.5 /-2.8)\end{array}$ & $\begin{array}{c}2.27 \\
(1.1 / 3.4)\end{array}$ & $\begin{array}{c}158.3 \\
(3 / 765)\end{array}$ & $\begin{array}{c}57.7 \\
(42 / 85) \\
\end{array}$ & $\begin{array}{c}75 \\
(48 / 87) \\
\end{array}$ \\
\hline 7 & $\begin{array}{l}\text { Göktepe } 3 \\
\quad(72)\end{array}$ & $\begin{array}{c}0.62 \\
(0.2 / 1.3)\end{array}$ & $\begin{array}{c}-3.33 \\
(-6.6 /-2.6)\end{array}$ & $\begin{array}{c}2.11 \\
(-4.6 / 3.4)\end{array}$ & $\begin{array}{c}3.5 \\
(1 / 14)\end{array}$ & $\begin{array}{c}53.9 \\
(45 / 64)\end{array}$ & $\begin{array}{c}82 \\
(40 / 99)\end{array}$ \\
\hline 8 & $\begin{array}{l}\text { Göktepe } 4 \\
(27)\end{array}$ & $\begin{array}{c}0.62 \\
(0.1 / 1.1)\end{array}$ & $\begin{array}{c}-3.19 \\
(-5.3 /-2.2)\end{array}$ & $\begin{array}{c}2.15 \\
(-1.5 / 2.7)\end{array}$ & $\begin{array}{l}19.8 \\
(3 / 47)\end{array}$ & $\begin{array}{c}46.2 \\
(37 / 51)\end{array}$ & $\begin{array}{c}85 \\
(54 / 98)\end{array}$ \\
\hline 9 & $\begin{array}{c}\text { Göktepe 4b } \\
(5)\end{array}$ & $\begin{array}{c}0.62 \\
(0.5-0.8) \\
\end{array}$ & $\begin{array}{c}-2.91 \\
(-3.1 /-2.8) \\
\end{array}$ & $\begin{array}{c}2.55 \\
(2.4 / 2.6) \\
\end{array}$ & $\begin{array}{c}237.7 \\
(165 / 303) \\
\end{array}$ & $\begin{array}{c}(47.0) \\
(46 / 48) \\
\end{array}$ & $\begin{array}{c}89 \\
(85 / 91) \\
\end{array}$ \\
\hline
\end{tabular}

MGS, maximum grain size; EPR, electron paramagnetic resonance. The isotopic and EPR variables are given in \%o or \% with respect to specific standards (Pee Dee Belemnite for isotopes and Dolomite N368 BCS for EPR) (Herz 1985, 1987, 1988). The colour value is expressed as \% in an 8-bit scale where 0 represents black and 255 white.

Table 2. Results of the analysis.

No. Description
Sabine sample Florida Project $\quad$ Carrara
$1 \quad$ Relative prob. (\%)
Distance a.u., distance of the sample under consideration from the centre of the ellipse that represents the quarry probability field (the central point of the ellipse expresses the average and hence most character-
istic values of a quarry, the closer a point is to the centre of an ellipse, the more likely is the provenance from that marble site); relative prob., relative (posterior) probability of the sample to belong to some group
within the assumption that it originates in any case from one of the groups in the selection (the threshold is $60 \%$, with low values indicating that the sample's assignment is in doubt between two or more groups);
absolute probab., a distance dependent parameter measuring the absolute probability that the sample belongs to the chosen group or, in other words, is a typical representative of the group properties [the thresh-
old is 10\% corresponding to samples on the edge of the $90 \%$ probability ellipse, with low values indicating anomalous samples (outliers) or samples possibly not belonging to any group in the selection].




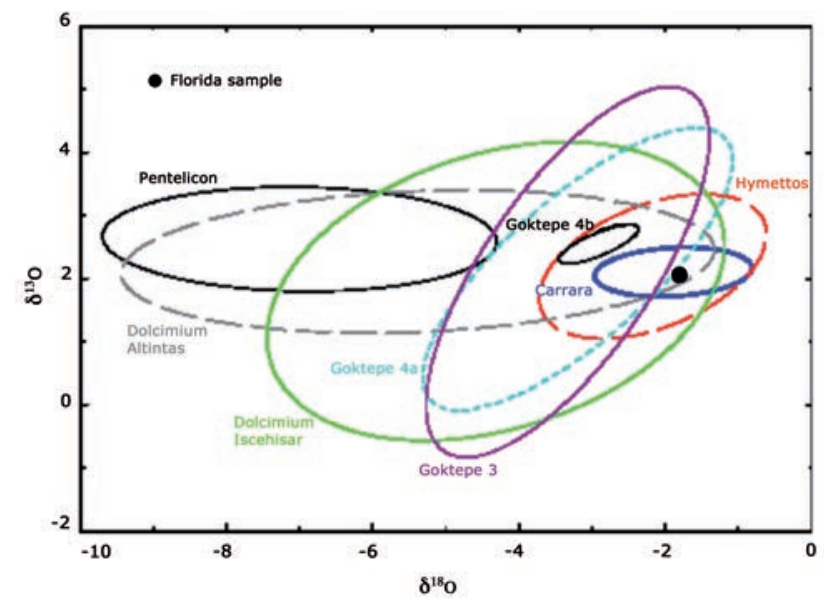

Figure 4. Isotopic comparison graph.

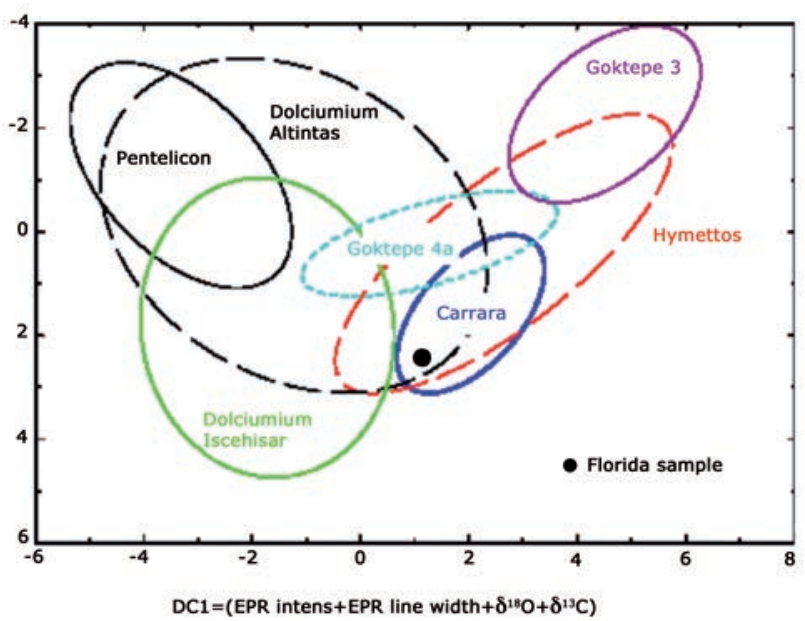

Figure 5. Statistical comparison graph. six sites which produced fine grained marbles. Any alternative provenance would be ruled out by the statistically based procedure of data analysis in the quantitative determination of provenance. The six sites taken into account are: Carrara, Pentelicon, Hymettos, Docimium (Iscehisar), Docimium (Altintaş), Göktepe (3 groups). Iscehisar and Altinta are the two locations in ancient Phrygia where the famous coloured marble called pavonazzetto was produced. The two sites, however, produced also one of the best white statuary marbles quarried in Asia Minor and generally called Docimium from the name of the Roman city near to the quarries. Göktepe is less known. The site, located in Caria in the territory of Aphrodisias, has been discovered only a few years ago and is proving since then to be one of the most important sources of white as well as black statuary marbles used in imperial time (Attanasio et al., 2009). The fact that it was used mostly by the sculptors of Aphrodisias, where a strong marble carving tradition existed, makes even more important the role played by this marble. It may be noted that the database selection includes six marble sites but eight marble groups. This is due to the fact that Göktepe, like many other ancient marble sites, produced different marbles varieties which are coherently distributed into different districts. The EPR intensity of the different varieties differs appreciably. Separate classification of the different varieties allows to obtain much improved discrimination (Polikreti and Maniatis, 2002).

Inspection of Table 1 confirms that Carrara provides the best fit for the properties of the Sabine sample. This qualitative conclusion if fully supported by the quantitative results.

The results of the analysis are as follows (Table 2): the isotopic (Figure 4) and statistical (Figure 5) graphs are two dimensional representations of a multi-dimensional problem.
As such they are useful for illustrative purposes of comparing the ancient quarries. This is the result of calculations which take into account all the variables and properties used to characterise the samples and is expressed in terms of the distance and the probability parameters given before.

\section{Discussion}

The analytical results indicate that the Sabine sample is a fine grained marble (MGS $=0.7 \mathrm{~mm}$ ) and the analytical properties are summarised by the means and by the total variability range of the analytical variables found in Table 1. Therefore, its provenance can be established within the marble database of ancient Carrara quarry samples.

The ancient Carrara quarries were located in the Apuan Alps, part of the northern Apennines range in Italy. Only sporadic quarrying existed before the $1^{\text {st }}$ century B.C., but during the $1^{\text {st }}$ and $2^{\text {nd }}$ century A.D. this marble called Luna in ancient times because of the Luna town's proximity to the Carrara Mountains - became a supply source for building in Rome. The use of the ancient (Luna) Carrara quarry peaked during the time of Trajan 98 to 117 A.D. In the $2^{\text {nd }}$ century Carrara was quickly replaced by other marbles originating from the Eastern Mediterranean, particularly the white Proconnessos type. By the end of the $2^{\text {nd }}$ century eastern white marbles had become the supply source for building and decorative needs like sculpture and funerary reliefs. This fact provides ease of dating Roman marble artifacts based on the ancient quarry of provenance.

\section{Conclusions}

The study shows that the analysed marble comes from an ancient Roman quarry in the Etruria region of Italy and was carried to Rome where it was worked. The marble sample from the sarcophagus was scientifically analysed against 524 other samples. The isotopic, EPR evidence and the colour value percent of the Sabine sample of ancient Carrara (Luna) marble also have a high match to other database samples including marble from The Pantheon, Rome (completed 126 A.D.), the Sarcophagus with Three Pairs of Captive Amazons, London (180-220 A.D.), Trajan's Column, Rome (completed 113 A.D.), and the Sarcophagus of the Triumph of Bacchus, Lyon (ca. 200 A.D.). This qualitative conclusion is fully supported by the quantitative results and thus the dating of the Sabine sarcophagus as $c a$. $2^{\text {nd }}$ century A.D. is extremely accurate.

\section{References}

Attanasio D, Brilli M, Ogle N, 2006. The isotope signature of Classical marbles. L'Erma di Bretschneider ed., Rome, Italy.

Attanasio D, Bruno M, Yavuz AB, 2009, Quarries in the region of Aphrodisias: the black and white marbles of Göktepe (Muğla, Turkey). J Roman Archaeol 22:312-48.

Frothingham AL, 1922. The Ludovisi Sarcophagus and the dating of Roman Sarcophagi. Princeton University Press, Princeton, NJ, USA.

Herz N, 1985. Isotopic analysis of marble. In: Rapp GJ and Gifford JA, eds. Archaeological geology. Yale University 
Press, New Haven, CT, USA, pp 331-51.

Herz N, 1987. Carbon and oxygen isotopic ratios: a database for classical Greek and Roman marble. Archaeometry 29:35-43.

Herz N, 1988. The oxygen and carbon isotopic database for classical marble. In: Herz $\mathrm{N}$ and Wealkens M, eds. Classical marble: geochemistry, technology, trade. Kluwer
Academic, Boston, MA, USA, pp 305-14.

Moens L, Roos P, De Paepe P, Scheurleer RL, 1992. Provenance determination of white marble sculptures from the Allard Pierson Museum in Amsterdam, based on chemical, microscopic and isotopic criteria. In: Waelkens M, Herz N and Moens L, eds. Ancient stones: quarrying, trade and provenance. Leuven University Press, Leuven, Belgium, pp 269-76.

Polikreti K, Maniatis Y, 2002. A new methodology for marble provenance investigation based on EPR spectroscopy. Archaeometry 44:1-21. 